\title{
Analysis of the Increasing US-China Military'Tension in the South China Sea and the Challenges for Indonesia
}

\author{
Erti Fadhilah Putri ${ }^{1^{*}}$, Kukuh Setyo Pambudi ${ }^{2}$, Agus Adriyanto ${ }^{3}$ \\ 1,2,3 Universitas Pertahanan \\ *Correspending author: ${ }^{1 *}$ ertifadhilahputri01@gmail.com, ${ }^{2}$ kukuhpambudi@ymail. \\ com, ${ }^{3}$ a.adriyanto@yahoo.com.
}

Abstract: Nowadays, the United States shows its foreign policy focus to the Asia Pacific region where there is a border conflict between China and the countries in the Southeast Asia Region. This paper tries to analyze the increasing tension of the US and Chinese military forces in the South China Sea and see how the challenges Indonesia will face with the escalation in the South China Sea. The United States of America began to increase its military power aimed to overseeing the South China Sea and Chinese Hegemony. The increase in US military strength certainly threatens China's interests in the South China Sea so that even in the middle of Covid-19, China is showing its military strength by conducting patrols and joint exercises in the waters of southern China. The improvement of the two superpowers can be seen in the framework of the Balancing Power theory, which emphasizes the analysis of military force tension in both countries. Whereas in analyzing the challenges faced by Indonesia, it can use the Balance of Threat theory. The purpose of this paper is to provide recommendations for the Indonesian government in dealing with the increasing tension in the South China Sea.

Keywords: balance of threat theory; Indonesia; military tension; South China sea

\section{Introduction}

The dynamics of the conflict in the South China Sea are entering a new chapter. The two countries that are the main actors, namely China and the 
United States, have shown fierce rivalries in influencing the South China Sea region. China has shown its controversial aggressive response to the United States' meddling in the South China Sea conflict. The Chinese Embassy in the United States stated that the interference of the United States in the South China Sea issues had aroused tensions and triggered confrontation in the region. ${ }^{1}$ On the contrary, the aggressive action that the United States has taken is a form of rejection of China's historical claim to the nine-dash line area and calls for freedom of shipping. ${ }^{2}$

On several occasions, the Commander of the United States Pacific Fleet, Rear Admiral Jim Kirk, stated that the efforts made by the United States today are a form of commitment to a free and open Indo-Pacific based on international rules and commitments of allies and partners in the region. In addition, the political motivation for action that underlies America is the Balance of Power of the United States in the Asia-Pacific region which is starting to be dominated by China. ${ }^{3}$ The presence of the two US warships in the waters of the South China Sea is a dilemma in itself for China and its ambitions in the region. In response to aggressive United States action, China launched four medium-range ballistic missiles at a military exercise by the PLA. On several occasions, officials from China also mentioned that the launch of this medium-range ballistic missile was a form of Chinese protest against the presence of the two US warships in the waters of the South China Sea. Referring to the form of action taken by China, it is a form of deterrence against the United States as a potential aggressor. ${ }^{4}$

The condition of the South China Sea which is getting warmer, of course, also has an impact on the countries around the waters. Countries that also claim waters in the South China Sea are also starting to guard against the dynamics taking place in the South China Sea. one example is that Malaysia is a country that firmly rejects China's claims in the South China Sea and begins to legalize its claim to the remaining part of the continental shelf beyond 200 nautical

1 Evelyn Cheng. 2020. China says the latest U.S. move is aggravating tensions in the South China Sea. July 13. Accessed September 15, 2020. https://www.cnbc.com/2020/07/14/china-says-the-us-isaggravating-tensions-in-the-south-china-sea.html.

2 Ankit Panda. 2020. US Conducts Freedom of Navigation Operation Near China-Held Features in Spratlys. July 15. Accessed September 15, 2020. https://thediplomat.com/2020/07/us-conducts-freedom-of-navigation-operation-near-china-held-features-in-spratlys/.

3 M.Najeri Al Syahrin. 2018. Keamanan Asia Timur Realitas, Kompleksitas dan Rivalitas. Depok: Komojoyo Press.

4 Babb, Carla. 2020. China Launches 4 Missiles into South China Sea. WASHINGTON, August 27 
miles from the base to the United Nations (UN) in mid-August. ${ }^{5}$ The Malaysian government responding to China's nine-dash line claim that claims made by China have no basis whatsoever under international law. Apart from fighting for the legal aspects of the waters claimed by Malaysia from the aspect of international law. Malaysia is also preparing for the development of militaristic issues in the waters, Malaysia has begun to pay more attention on several occasions. The King of Malaysia revealed that Malaysia's defense strategy needs to be developed taking into account the geopolitics of the South China Sea region. ${ }^{6}$

Apart from the drastic change in climate of the countries that also claim the waters in the South China Sea. Indonesia as a country in the South China Sea region is also influenced by the regional climate. In its diplomatic note, Indonesia emphasized that Indonesia is not a party to the South China Sea dispute. Indonesia respects international maritime law and rule of law in international relations. In responding to problems in the South China Sea involving some ASEAN members, Indonesia as part of Asean, trying peaceful efforts to maintain regional stability by offering peaceful efforts to resolve tensions in the countries around the region, such as promoting the stability of the Code of Conduct which was initiated in 2002 which aims to establish a stable area and prevent competing maritime boundary claims from becoming conflicts. ${ }^{7}$

The increase in military tension in the region and the aggressive actions of the United States and China have raised concerns over the development of escalation in Indonesia. Indonesia has begun to seek Balance of Threat measures ${ }^{8}$ and annul actual threats that could threaten national security. Indonesia is starting to show its strength and assertiveness in the Southeast Asia region. The Indonesian Navy carries out military exercises in the Natuna Islands near the waters of the Ninedash line. The development of military issues in this region certainly makes Indonesia more adaptable to the possibility of military confrontation. So that

5 Nisah Shukry. 2020. Malaysia Issues Rare Rebuke Against China Over South China Sea. August 13. Accessed September 15, 2020. bloomberg.com/news/articles/2020-08-13/malaysia-issues-rare-rebukeagainst-china-over-south-china-sea.

6 Yusof, Amir. 2020. Malaysia needs to pay attention to increased activities by big powers in the South China Sea: King. May 18. Accessed September 15, 2020. https://www.channelnewsasia.com/news/asia/malaysia-king-south-china-sea-pay-attention-parliament-12744852.

7 Robert C. Backman. 2015. "ASEAN and South China sea dispute." In Entering Uncharted Waters? Asean and South China, 15-20. Singapore: Institute of Southest Asia Studies.

8 Syailendra, Emirza Adi. 2017. "A Nonbalancing Act: Explaining Indonesia's Failure to Balance Against the Chinese Threat." Asian Security 237-238. 
in the problems faced now, how does Indonesia see the challenges ahead with a balance of threat approach in regional geopolitics.

\section{Geopolitic Conditions of South China Sea}

The heated conditions in the South China Sea are not only a stage for the two superpowers to show their rivalry. Allied and partner countries are also involved in the warming of the South China Sea region. The South China Sea is a strategic water area in the world which is the commercial gateway for the logistics industry in the world that crosses the waters. The total value of trade across these waters was around 3.37 trillion in 2016. In addition to the logistical supply of the South China Sea Region, 40 per cent of global liquefied natural gas also passes. In addition to its strategic position, natural wealth in the form of biological and mineral wealth makes this area of high value.?

The militarization of Chinese power in the South China Sea began in 2009 with Beijing trying to legitimize and secure its disputed territorial claims in the South China Sea. As soon as China submitted a map to the United Nations including its nine-dashed territorial claim in the South China Sea on May 7, 2009, the Philippines filed a diplomatic protest against China for claiming the entire South China Sea illegally. Vietnam and Malaysia filed a joint protest a day after China submitted its maps to the United Nations. Indonesia also registered its protests, although it has no claim to the South China Sea. The existence of protests brought to the country of China did not stop China from continuing its ambitions in the South China Sea. ${ }^{10}$

China began upgrading new military facilities at outposts on the Paracel and Spratly islands as well as conducting sovereign patrols in the region. However, China has not yet deployed the People's Liberation Army Navy (PLAN) of the People's Liberation Army Air Force (PLAAF) to the base of operations. Before the existence of INDOPACOM in April 2018, the United States had issued a policy of 'Pivot to Asia' which is an expression of a strategy focused on the AsiaPacific Region. This strategy can show that the United States is doing a balancing strategy or balancing the Asia Pacific region with the presence of China as a rising power. The United States realizes that China's military advances in the last

9 Thea Fathanah, Arbar. 2020. Klaim China E Harta Karun Migas di Laut China Selatan. July 25. Accessed September 15, 2020.

10 Robert C. Backman. 2015. "ASEAN and South China sea dispute." In Entering Uncharted Waters? Asean and South China, 15-20. Singapore: Institute of Southest Asia Studies. 
decade can affect the climate of the Asia-Pacific region and can certainly rival the influence of the United States in the region. ${ }^{11}$

The increasing actions of Chinese aggression during this period also triggered the United States to start paying attention to the South China Sea, where previously there had been trading disputes and termination of diplomatic relations. In the chronology of the United States military tension starting at the end of April, the Pentagon began deploying the warships USS Bunker HILL, USS America and USS Barry to the waters of the South China Sea. ${ }^{12}$ The action taken by the United States is a form of deterrence strategy which indeed seeks to change geopolitics in the South China Sea region. In the concept of deterrence, Huth and Russet (1988) state that there are two types of detergents based on their conditions, namely Direct-Deterrent and Extend Deterrent. Direct Detergent is a prevention strategy so that potential aggressors do not attack the country or prevent the country's territory from being attacked by potential aggressors.

Meanwhile, Extend Detergent is a strategy to prevent the territorial state that being attacked and prevent attacks that lead to allied countries. In the context of the United States, the deterrence strategy has been used since the cold war involving eastern bloc countries. ${ }^{13}$ The efforts made by the United States can be classified as Extend Deterrent wherein the context of the waters of the China Sea, the United States does not only prevent potential aggressors from attacking their country but also protects its allied countries. In mid-May, increased tension continued with the deployment of the USS Rafael-class destroyer, which began passing around the coast near Shanghai. Besides, America also deployed the MQ-4C Triton spy drone that flew in the waters of the South China Sea. On several occasions, the Peking University Think Tank Institute also confirmed that there was a United States warship sailing 12 miles from Cuarteron Reef in the Spratly Islands. Where the region is a disputed area between China and the Philippines. The deployment of military forces to the South China Sea region is the first time for the United States, and this certainly shows the level of issue that the United States is very concerned. ${ }^{14}$

11 Danah Ali Alenezi. 2020. "US rebalance strategy to Asia and." Review of Economics and Political 4-8.

12 Barratut Taqiyyah Rafie. 2020. "AS-China kerahkan kapal perang, ini kronologi tingginya tensi di Laut China Selatan." internasional kontan. Mei 19. Accessed September 15, 2020. https://internasional.kontan.co.id/news/as-china-kerahkan-kapal-perang-ini-kronologi-tingginya-tensi-di-laut-chinaselatan.

13 Mazarr, Michael J. 2020. "Understanding Deterrence." Understanding Deterrence 3.

14 Sebayang, Rehia. 2020. Fakta Potensi Pereang China-AS di Laut China selatan. July 03. Accessed september 15, 2020. https://www.cnbcindonesia.com/news/20200703161139-4-170070/fakta-potensi- 
Seeing the dynamics occurring in the South China Sea as well as the high bargaining position, external actors also have regional climate influence apart from the United States. The actions taken by the United States have dragged other regional actors such as Australia, India, Japan. The four countries secretly formed the Quadrilateral Security Dialogue or "Quad". ${ }^{15}$ This security dialogue is an informal dialogue to coordinate security and military policies in favour of China covertly. The existence of the Quad defence dialogue indicates the efforts of the four-nation group to balance China's security in the South China Sea and control the Indo-Pacific region. These four countries have also met at least five times since 2017. India is one of the members who seem to be concerned about the issue of China's development in the South China Sea. Apart from joining India into the Squad, India has also changed its previous "Look East" policy to "Act East" which shows the direction of India's foreign policy towards the South China Sea region. India has also strengthened defence relations with the central counter-claimant countries of ASEAN. One example is the India-AustraliaIndonesia trilateral security dialogue. ${ }^{16}$

India's involvement is increasingly evident in the South China Sea, as soon as India reportedly deployed warships to the South China Sea, India's aggressive actions are also a form of India's response to clashes with China on the Himalayan border. The geopolitical situation in the region has become increasingly cloudy with the presence of the United States' partners and alliances by bringing in warships in the waters of the South China Sea. Besides, the holding of various joint exercises has also made the geopolitical climate even hotter by starting a confrontation and the potential for conflict to develop. ${ }^{17}$

\section{The Possibility of Confrontation in the South China Sea}

China's dynamic attitude has prompted other regional powers to seek a balance of power strategy. Strategy refers to the outcome at the systemic or sub-systemic level, that is, the state of power equilibrium among the key actors.

perang-china-as-di-laut-china-selatan.

15 CSIS. 2020. Defining the Diamond: The Past, Present, and Future of the Quadrilateral Security Dialogue. CSIS.

16 EFSAS. 2020. From Look East to Act East: India's Changing Posture in the Indo-Pacific and the Containment of China. Amsterdam: European Foundation for South Asian Studies.

17 Brewster, David. 2020. India-China conflict:A move from the Himalayas to the high seas? July 10. Accessed September 15, 2020. https://www.lowyinstitute.org/the-interpreter/india-china-conflictmove-himalayas-high-seas. 
The purpose of balancing is to prevent a rising power or dominant form from assuming supremacy, and if and when the effort is successful, a balance of power is expected to emerge. Even though the purpose is done by the United States and its allies in the waters of the South China Sea, even though the balancing strategy cannot reduce the power of a country, however, it is only limited to offsetting so that the current attack strategy may turn into a confrontation of military forces in the Asia Pacific region.

The military confrontation that began to develop was accompanied by a cold war between the two superpowers. Despite previous US policies calling for a peaceful settlement of the South China Sea dispute between China and its neighbours, US Secretary of State Mike Pompeo recently announced a much tougher decision. In an official statement on July 13, he stated that "Beijing's claims to offshore resources across most of the South China Sea are completely unlawful, as is its campaign of bullying to control them." The United States supports our Southeast Asian allies and partners in protecting them. Their sovereign rights." At the end of July, the Foreign Minister's tough stance was also aimed at fighting and ending the oppression. ${ }^{18}$

Some experts are starting to predict the development of the issue that will occur in the South China Sea. One of them is Blake Herzinger, a specialist in Indo-Pacific civil defence policy. Blake Herzingar revealed that "the South China Sea wouldn't start a war, but there's a risk of miscalculation that could result in localized hostilities". The South China Sea is currently not about to start a war, but there is a risk of a miscalculation which could result in local hostilities. ${ }^{19}$ Blake also considered that the two countries would act appropriately to try and takedown in the event of an attack. ${ }^{20}$ While real military confrontation always looms large, many experts believe that China prefers to wage political and economic warfare to weaken the US and advance its strategic objectives. Unlike most other US adversaries, competition with China is a broad global competition that has a non-military aspect that is very strong. Countless, as China seeks to dominate the region politically and economically, create economic conditions that benefit China alone, and replace democratic institutions. Like the Cold War

18 Wittner, Lawrence. 2020. Citizen For Global Solutions. August 10. Accessed september 15, 2020. https://globalsolutions.org/china-and-the-united-states-could-avoid-an-unnecessary-war/.

19 Military Times. 2020. What war with China could look like. september 1. Accessed september 15, 2020. https://www.militarytimes.com/news/your-army/2020/09/01/what-war-with-china-could-looklike/.

20 Military Times. 2020. 
of the 20th century, geostrategic battles between the US and China could escalate without peer-to-peer warfare direct.

\section{Indonesia's Position and Potential}

Some experts are starting to predict the development of the issue that will occur in the South China Sea. One of them is Blake Herzinger, an observer in Indo-Pacific civil defence policy. Blake Herzingar revealed that "the South China Sea wouldn't start a war, but there's a risk of miscalculation that could result in localized hostilities". The South China Sea is currently not about to start a war, but there is a risk of a miscalculation which could result in local hostilities. Blake also considered that the two countries would act appropriately to try and takedown in the event of an attack..$^{21}$ While real military confrontation always looms large, many experts believe that China prefers to wage political and economic warfare to weaken the US and advance its strategic objectives. Unlike most other US adversaries, competition with China is a broad global competition that has a non-military aspect that is strong. Countless, as China seeks to dominate the region politically and economically, create economic conditions that benefit China alone, and replace democratic institutions. Like the Cold War of the 20th century, geostrategic battles between the US and China could escalate without peer-to-peer warfare. ${ }^{22}$

The increase in military tension in the region and the aggressive actions of the United States and China have raised concerns over the development of escalation in Indonesia. Indonesia has begun to seek Balance of Threat measures and to eliminate actual threats that could threaten national security. In the theory of balancing threats or Balance of Threat, it is stated that the behaviour of state alliances is determined by the threat they feel from other countries. Walt argues that states, in general, will balance by allying against perceived threats, but very weak states are more likely to participate with increasing threats to protect their own security. ${ }^{23}$

Previously, the increasing military tension in Indonesia's southern China

21 Military Times. 2020.

22 Kinling Lo. 2020. South China Morning Post. January 22. Accessed Sepyember 15, 2020. cmp.com/ news/china/diplomacy/article/3044374/how-indonesias-south-china-sea-dispute-beijing-couldlead.

23 Widian, Rizky. 2020. "Analisis perimbangan ancaman tentang kebijakan Indonesia di Laut Tiongkok Selatan tahun 2009-2017 = Balance of threat analysis on Indonesia s policy in the South China sea from 2009-2017." Post Graduate Thesis 65-70. 
Sea has seen China's potential in the waters of the South China Sea. In an effort to counterbalance the threat, Indonesia has begun to carry out a series of strategies, namely to turn Indonesia into a Global Maritime Axis. ${ }^{24}$ The Global Maritime Axis, which was initiated by President Jokowi, is a response to the global geopolitical trend that is tending towards the Indo-Pacific. There are also many actors with major powers like China, with their military and economic strength trying to dominate the Asia Pacific region. This Global Maritime Axis also indicates that Indonesia has a strategic policy in advancing a maritime-based economy. ${ }^{25}$ However, this policy was not implemented properly. There are several reasons why the Global Maritime Axis policy is not working well, namely the conflicting interests of Indonesian actors and their different perceptions of the Chinese threat resulting in a lack of consensus on how to respond to China.

The existence of multiple views regarding the nature of the Chinese threat has prevented Indonesia from making a coherent response to Beijing. At present, Indonesia's involvement in China is strongly driven by President Jokowi's personal interest in adjudicating short to medium term investment from China, in part to improve his election prospects. Although this policy is supported by several segments of society in Indonesia such as business interests, it is also opposed by many who believe that dependence on China will limit Indonesia's strategic autonomy. ${ }^{26}$ The current tensions have changed several Indonesian policies. Where previously Indonesia had indeed acted more diplomatically against threats originating from the South China Sea, then Indonesia's defensive active defence doctrine made Indonesia have to protect the country's sovereignty from foreign invasion. ${ }^{27}$ The heating up of military tension in the South China Sea certainly requires measuring the military strength of the countries involved. The issue of threats is important for Indonesia amidst the heated South China Sea issue.

Indonesia is currently focusing on increasing its capabilities in facing the existing threats. On several occasions, Indonesia has also organized large-scale marine training. The last major Indonesian marine military exercise was held at the end of July 2020. This was also a response to the increasing tensions between China and the United States in the waters of the South China Sea. Indonesia is

24 Emirza Adi Syailendra. 2017.

25 Yani Yanyan M, and Montratama Ian. 2015. "INDONESIA SEBAGAI POROS MARITIM DUNIA: SUATU TINJAUAN GEOPOLITIK.” Jurnal Pertahanan dan Bela Negara 28.

26 Emirza Adi Syailendra. 2017.

27 Fajri, M. Bahtiar. 2020. "STRATEGI PERTAHANAN MARITIM INDONESIA DI TENGAH." Jurnal Penelitian Politik 69-70. 
also holding training with Malaysia, namely amphibious warfare exercises on the beach in Singkep, an island in the Riau chain in the South China Sea. A military observer at the Indonesian Institute for Defense and Strategic Studies said the exercise was part of an effort state to assert its maritime sovereignty. ${ }^{28}$ Some steps that have been taken in anticipation of increasing military tension in the region are reasonable. This is because the tensions that occur have long been predicted and have not resulted in a mutually binding and respected agreement.

\section{Conclusion}

Many predict that the South China Sea will become a new tension zone in Southeast Asia. This tension has been made more apparent by the entry of the two most considerable military powers in the world, namely the United States and China. Likewise, countries whose territories are disputed areas have also prepared by increasing their military strength and holding large-scale military exercises in the South China Sea region. This condition can be a very worrying threat to Indonesia. But on the other hand, the conditions that occur in the South China Sea can also be an opportunity to be exploited especially for Indonesia. Indonesia, as the largest country, both in terms of region, influence, and militarily in Southeast Asia, can take a more significant role by mediating the tensions that occur. This opportunity is possible if Indonesia can consolidate the countries in ASEAN to accelerate the approval of the Code of Conduct. Besides, encouraging the existence of an ASEAN forum in discussing the future of the South China Sea can be started by Indonesia as well as holding multilateral talks usually. Finally, it is urgent to realize the consolidation of military forces and supporters in the Natuna region. Indonesia must be prepared for any possibility, including the worst case of war and armed conflict in the South China Sea.

\section{Reference}

Alenezi, Danah Ali. 2020. "US rebalance strategy to Asia and." Review of Economics and Political 4-8.

Babb, Carla. 2020. China Launches 4 Missiles into South China Sea. WASHINGTON, August 27.

28 Nirmala, Ronna. 2020. Indonesian Navy Conducts Major Exercise amid South China Sea Tensions. jakarta , July 22. 
Backman, Robert C. 2015. "ASEAN and South China sea dispute." In Entering Uncharted Waters? Asean and South China, 15-20. Singapore: Institute of Southest Asia Studies.

Brewster, David. 2020. India-China conflict:A move from the Himalayas to the bigh seas? July 10. Accessed September 15, 2020. https://www.lowyinstitute. org/the-interpreter/india-china-conflict-move-himalayas-high-seas.

Cheng, Evelyn. 2020. China says the latest U.S. move is aggravating tensions in the South China Sea. July 13. Accessed September 15, 2020. https://www. cnbc.com/2020/07/14/china-says-the-us-is-aggravating-tensions-in-thesouth-china-sea.html.

CSIS.2020. Defining the Diamond: The Past, Present, and Future of the Quadrilateral Security Dialogue. CSIS.

EFSAS. 2020. From Look East to Act East: India's Changing Posture in the IndoPacific and the Containment of China. Amsterdam: European Foundation for South Asian Studies.

Fajri, M. Bahtiar. 2020. "STRATEGI PERTAHANAN MARITIM INDONESIA DI TENGAH.” Jurnal Penelitian Politik 69-70.

Lo, Kinling. 2020. South China Morning Post. January 22. Accessed Sepyember 15, 2020. cmp.com/news/china/diplomacy/article/3044374/how-indonesiassouth-china-sea-dispute-beijing-could-lead.

Marsetio. 2020. Covid-19 dan Hegemoni AS di Laut China Selatan. Jakarta, April 2020.

Mazarr, Michael J. 2020. “Understanding Deterrence.” Understanding Deterrence 3.

Military Times. 2020. What war with China could look like. september 1. Accessed september 15, 2020. https://www.militarytimes.com/news/yourarmy/2020/09/01/what-war-with-china-could-look-like/.

Nirmala, Ronna. 2020. Indonesian Navy Conducts Major Exercise amid South China Sea Tensions. jakarta , July 22.

Panda, Ankit. 2020. US Conducts Freedom of Navigation Operation Near China-Held Features in Spratlys. July 15. Accessed September 15, 2020. https://thediplomat.com/2020/07/us-conducts-freedom-of-navigationoperation-near-china-held-features-in-spratlys/.

Planifolia, Vanilla. 2017. "Strategi Rebalancing Amerika Serikat." JURNAL HUBUNGAN INTERNASIONAL 4. 
Rafie, Barratut Taqiyyah. 2020. "AS-China kerahkan kapal perang, ini kronologi tingginya tensi di Laut China Selatan.” internasional kontan. Mei 19. Accessed September 15, 2020. https://internasional.kontan.co.id/news/ as-china-kerahkan-kapal-perang-ini-kronologi-tingginya-tensi-di-lautchina-selatan.

Sebayang, Rehia. 2020. Fakta Potensi Pereang China-AS di Laut China selatan. July 03. Accessed september 15, 2020. https://www.cnbcindonesia.com/ news/20200703161139-4-170070/fakta-potensi-perang-china-as-dilaut-china-selatan.

Shukry, nisah. 2020. Malaysia Issues Rare Rebuke Against China Over South China Sea. August 13. Accessed September 15, 2020. bloomberg.com/news/ articles/2020-08-13/malaysia-issues-rare-rebuke-against-china-oversouth-china-sea.

Syahrin, M.Najeri Al. 2018. Keamanan Asia Timur Realitas, Kompleksitas dan Rivalitas. Depok: Komojoyo Press.

Syailendra, Emirza Adi. 2017. "A Nonbalancing Act: Explaining Indonesia's Failure to Balance Against the Chinese Threat." Asian Security 237-238.

Thea Fathanah, Arbar. 2020. Klaim China \& Harta Karun Migas di Laut China Selatan. July 25. Accessed September 15,2020. https://www.cnbcindonesia. com/news/20200724145935-4-175189/klaim-china-harta-karun-migasdi-laut-china-selatan.

Widian, Rizky. 2020. "Analisis perimbangan ancaman tentang kebijakan Indonesia di Laut Tiongkok Selatan tahun 2009-2017 = Balance of threat analysis on Indonesia s policy in the South China sea from 2009-2017." Post Graduate Thesis 65-70.

Wittner, Lawrence. 2020. Citizen For Global Solutions. August 10. Accessed september 15, 2020. https://globalsolutions.org/china-and-the-unitedstates-could-avoid-an-unnecessary-war/.

Yanyan M., Yani, and Montratama Ian. 2015. "INDONESIA SEBAGAI POROS MARITIM DUNIA: SUATU TINJAUAN GEOPOLITIK.” Jurnal Pertahanan dan Bela Negara 28.

Yusof, Amir. 2020. Malaysia needs to pay attention to increased activities by big powers in the South China Sea: King. May 18. Accessed September 15, 2020. https://www.channelnewsasia.com/news/asia/malaysia-king-southchina-sea-pay-attention-parliament-12744852. 